\title{
The Role of Law Enforcement on Moderating the Relationship between Government Size, Fiscal Decentralization, Audit Finding and Corruption
}

\author{
Khoirul Aswar $^{1, *}$, Ermawati $^{1}$, Jumansyah ${ }^{2}$, Mahendro Sumardjo $^{1}$, Anita Nopiyanti ${ }^{1}$ \\ ${ }^{1}$ Department of Accountancy, Faculty of Economics and Business, Universitas Pembangunan Nasional Veteran Jakarta, Indonesia \\ ${ }^{2}$ Department of Accountancy, Faculty of Economics and Business, Universitas Al-Azhar, Indonesia
}

Received October 6, 2021; Revised November 19, 2021; Accepted December 13, 2021

\section{Cite This Paper in the following Citation Styles}

(a): [1] Khoirul Aswar, Ermawati, Jumansyah, Mahendro Sumardjo, Anita Nopiyanti, "The Role of Law Enforcement on Moderating the Relationship between Government Size, Fiscal Decentralization, Audit Finding and Corruption," Universal Journal of Accounting and Finance, Vol. 10, No. 1, pp. 211-218, 2022. DOI: 10.13189/ujaf.2022.100122.

(b): Khoirul Aswar, Ermawati, Jumansyah, Mahendro Sumardjo, Anita Nopiyanti (2022). The Role of Law Enforcement on Moderating the Relationship between Government Size, Fiscal Decentralization, Audit Finding and Corruption. Universal Journal of Accounting and Finance, 10(1), 211-218. DOI: 10.13189/ujaf.2022.100122.

Copyright $\odot 2022$ by authors, all rights reserved. Authors agree that this article remains permanently open access under the terms of the Creative Commons Attribution License 4.0 International License

\begin{abstract}
This study is based on Indonesia's high levels of corruption, as evidenced by the Corruption Perception Index's low level (CPI). In Indonesia, the bulk of corruption cases involve local government entities. The objective of this study is to empirically examine the factors that contribute to high levels of corruption in local governments of district or city in Indonesia and the role of enforcement in that influence. This study applied a purposive sampling method to obtain a sample consisting of 66 district governments and 15 municipal governments in Indonesia in 2019. The data were analyzed by utilizing multiple linear regression techniques using Statistical Package for the Social Sciences (SPSS) version 25. The results of the analysis revealed that fiscal decentralization, government size, and audit findings have a significant positive with the level of corruption and law enforcement significantly moderates such relationship. This research contributes to auditing practices, government administration, law enforcement, and corruption control initiatives in the local government of Indonesia. Local government is also expected to be able to involve the role of the community to help oversee the running of a government which is free from corruption practices. Supervision also needs to be done by law enforcement officials, especially those dealing with corruption cases. Law enforcement officers are expected to be able to supervise and crack down on perpetrators of corrupt
\end{abstract}

practices.

Keywords Corruption, Law Enforcement, Fiscal Decentralization, Audit Findings

\section{Introduction}

Since the end of the New Order era, the Government of Indonesia has made improvements in the handling and eradication of criminal acts of corruption in Indonesia. Since the late 1990s, when structural changes caused economic and political crises in Indonesia, the government has been working hard to eliminate corruption by reforming laws, decentralization, and rule of law enforcement. The Indonesian people were encouraged to become more democratic, decentralized, and deregulated as a result of this incident [1]. One of the improvements made by the Indonesian government is to publish Law No. 31 of 1999 concerning Eradication of Corruption Crimes. Furthermore, Law No 20 of 2001 is one form of the serious efforts of the government after the reforms to prevent and act against perpetrators of corrupt practices. As a supporter in implementing the law, the government appointed 3 law enforcement agencies to handle and act on cases of corruption in Indonesia. The 
three law enforcement agencies are the Indonesian National Police, the Indonesian Attorney General's Office, and the Corruption Eradication Commission. However, the Indonesian Corruption Watch (ICW) assessed that during 2017-2019. It is reported that 2 out of 3 law enforcement agencies have experienced a decline of corruption cases [2].

The international scale through the Corruption Perception Index (CPI) in 2018, with a score of 38 points, Indonesia was ranked 89th out of 180 countries. This value is still below the average value obtained by countries in the Asia Pacific region and is a signal that the level of occurrence of corruption cases in Indonesia is still relatively high [3]. Based on the ICW monitoring in 2018, 454 corruption cases were handled by law enforcers involving 1,087 suspects and resulting in state losses of 5.6 trillion Rupiahs. From the 454 cases occurred, 218 cases involved the Regency and City Governments in Indonesia [4]. Anan [5] tried to explain this phenomenon by conducting study related to corruption level of local governments. He finds that the number of cases occurring in the regions is affected by fiscal decentralization. Ko and Zhi [6] explain if there are no supervision, the implementation of decentralization can be misused by local officials.

Indonesia's introduction of fiscal decentralization is one of the government's attempts to reduce the number of corruption cases in the country following the reform. The application is regulated in Act Number 22 of 1999 concerning Regional Autonomy and Act Number 25 of 1999 concerning Financial Balance Between Central and Regional Governments. The legislation governs the process of delegating authority and accountability from the federal government to regional governments in order for them to control resources in their respective areas independently. The management of resources independently by the regional government will be assisted by the central government through the provision of balance funds to realize equitable development in the regions and help the government to redistribute revenue [7]. The distribution of income from the central government determines the size of the government [8]. Goel and Nelson [9] and Liu and Lin [10] stated that the central government's vast income distribution to the regions has the potential to increase the number of cases of corruption.

Corruption remains a problem in Indonesia. Corruption happening in the government results in a decrease in the effectiveness and performance of government, income inequality, and poverty [11]. Deviations occurring during the practice of governance ought to be prevented as early as possible. Avis, Ferraz, and Finan [12] present that the auditing process reduces the occurrence of corruption cases in the future by $8 \%$. Examination mechanisms that prioritize the principles of transparency and accountability make auditing able to detect fraud as early as possible [13];
[14]; [15]. In Indonesia, fraud detection results are divided into two categories: shortcomings in the internal control mechanism and non-compliance with regulations. Weaknesses in internal control is a loophole of non-compliance with regulations resulting in corrupt practices in government [16].

According to Febrian and Rossieta [17], proof of government irregularities during the operational phase can be used as a basis for law enforcement officers to conduct further investigations. This action aims to prevent further corruption practices [18]; [19]; [14]. Previous study agrees that measuring effective corruption control is seen from preventive actions, detections and law enforcements by law enforcement agencies [20]; [21]. [22] rate that prevention and enforcement of corruption cases are very difficult to do. It is considered that corruption cases are not only confidential, but also a very beneficial reciprocal relationship. This effort will become more difficult when law enforcement officials compromise to corrupt practices [21]. According to Ko and Zhi's [6]) report, it is possible to mitigate the effects of fiscal decentralization on China's corruption level via law enforcement. Other results show that effective law enforcement decreases the number of instances of corruption in China local government.

Based on the foregoing phenomena and explanations, the aim of this research is to demonstrate the impact of government scale, audit findings and fiscal decentralization on the level of corruption in Indonesian local governments, with law enforcement as the moderating variable. This study moderates the law enforcement as a contribution to the literature. The use of audit findings is also based on recommendations from Adedeji, Soyinka, and Sunday [23] suggesting to add the influence of the internal control system and compliance with regulations.

\section{Literature Review and Hypothesis Development}

\subsection{Theoretical Perspective}

Agency relations occur not only in the private sector but also in the public sector. [24] states that agency theory explains the relationship of the public sector between the community and the government. The community as the owner of the resource entrusts its management to the government to manage public goods or services. The government is responsible for ensuring the equitable availability of public goods and services [25]; [9]; [8]. Siburian [27] explains that fiscal decentralization helps realize a more balanced income distribution which is tailored to the public needs in each region. Fiscal decentralization requires local governments to manage their fiscals from the transfer of power and authority from the central government to the regions [7]; [26]; [27]. To 
compensate this, the central government is required to surrender some of the fiscal resources to assist the implementation of development in the regions. However, the transfer of power from the center to other areas creates conflicts of interest and asymmetric information which leads to irregularities or violations committed by agents. Blackburn et al. [28] states the same thing. The delegation is possible to cause agency problems leading to corruption practices.

\subsection{Corruption}

Corruption is defined as behavior not complying with the principle which is done by agents in the private sector or public officials [29]. Cases of corruption in the public sector arise as a result of abuse of resources by government officials for personal gain. This occurs as a result of the two parties' differing interests and motivations, as well as asymmetrical information [30]. Hay and Cordery [31] suggest establishing a government audit institution to overcome agency problems. Audit institutions are formed to guarantee the quality of information and transparency of government entities ([15]; [13]. Audited local governments by audit institutions reduce the risk of future corruption cases [12]. It is caused by an auditing mechanism which not only ensures the accuracy of information but can also detect fraud in the government [18]; [10]; [14]. Fraud discovered during the audit process becomes an indication which leads to corruption cases [16]. In addition, the role of supervision from law enforcement agencies is able to overcome agency problems. It has been proven by Ko and Zhi [6] which states that the role of supervision done by law enforcement agencies reduces the number of corruption cases in local governments. Corruption cases can be effectively controlled by preventive actions, early detections and law enforcements created by law enforcement agencies [20]; [21].

There are many studies discussing the influencing factors of corruption level. One of them is the study from Dong and Torgler [32]. Their study was conducted with the aim to explain the factors causing corruption cases in 31 local governments in China. These factors include several aspects such as income, education, anti-corruption behavior, and regional characteristics. According to the findings, fiscal decentralization has the potential to reduce the number of local government corruption cases in China Fisman and Gatti [25], who conducted a cross-country study to determine the relationship between decentralization and corruption. They discovered that fiscal decentralization and government size could reduce the number of corruption cases in the countries.

Another cross-country study was also conducted by Malagueno [19] to find out the relationship that occurs between accounting, audit quality and corruption. This study used 37 countries as a comparison, with the findings indicating that countries with more transparent reporting had lower levels of corruption perception, and that perceptions of corruption could be lowered in a nation by enhancing accounting and auditing standards. Other audits has also been conducted in Indonesia as conducted by Suhardjanto et al. [39]. The study aims to determine the effect of audit opinion, follow-up of audit results and audit findings on the level of corruption in the provincial government. According to the results of this report, a growing of audit findings revealed that provincial government had committed violations during the operational phase that could lead to corrupt practices. This has implications for the high level of corruption caused by many violations committed by the provincial government. Furthermore, according to Ko and Zhi [6], if there are institutions regulating the delegation of central authority to the regions, the extent of corruption in local governments becomes controllable. They discovered that the relationship between fiscal decentralization and corruption could be moderated by law enforcement. In addition, they also found that strong law enforcement helped reduce the number of local government corruption cases in China.

\section{Hypotheses Development}

The hypotheses in this study are based on factors that are believed to have an impact on the corruption in the local government and law enforcement as a moderating, so it can be stated as follows:

\subsection{Government Size}

The agency theory framework closely spans the connection between the central and regional governments to accomplish income distribution and development [8]. To complete the goal, the central government provides resources to the regional government as an economic support for the region [7]. However, the differences in interests and motivations between local and central government are often discovered in the application. As revealed by Blackburn et al. [28], agency transactions between the center and the regions potentially cause agency problems which lead to irregularities and violations. Goel and Nelson [9] find that the larger the size of government, the more corruption cases are indicated [33] because the size of the government provides more public goods and services. Provision of public goods and services is often used by local officials for fraud and irregularities [6]; [34]. In addition, present data emphasizing that the highest frequency of corruption cases occur in local governments. Thus, the formulated the hypothesis as follows:

H1: The size of the government has a positive effect on the level of corruption. 


\subsection{Fiscal Decentralization}

The fiscal decentralization system requires local governments to independently manage their fiscal resources. Klitgaard in [24] states that agency theory explains the relationship of the public sector occurring between the community and the government. The central government delegates fiscal responsibility to regional governments to maximize the potential of resources in their regions. This maximization certainly involves the role of the local community to conduct surveillance and demand corrective action in deviations [25]. The implication is to make local governments more accountable and responsive [26]; [32]. In addition, A previous study found that fiscal decentralization aids in improving government efficiency [35]; [36]. Shah [37], on the other hand, claims that fiscal decentralization may have a greater negative effect on the unitary state than it does on the federal state. Indonesia, as a unitary state, has the potential to be negatively affected by decentralization effects. Being viewed from the corruption case data, the regional government ranks the most corrupt state agency. This statement is supported Anan [5] and Ulum et al. [38] explaining that the cause of the high number of corruption cases in Indonesia is caused by the implementation of fiscal decentralization. Thus, the formulated the hypothesis as follows:

H2: Fiscal decentralization has a positive effect on the level of corruption.

\subsection{Audit Findings}

Corruption is interpreted as a violation or deviation committed by an agent during the operational process [29]. Corruption is a form of agency problems caused by the mismatch of information reported by agents and differences in interests between agents and capital owners. Therefore, some suggest auditing to ensure the validity and accuracy of the information produced by the agent [15]; [13]; [31]. In addition, the auditing mechanism can also detect fraud committed during the operational process [18]; [19]; [14]. The findings of irregularities during the auditing process illustrate the regional government's non-compliance and the law internal control system. Weaknesses in internal supervision can be a loophole for violations leading to criminal acts of corruption [16]. Previously, study by Liu and Lin [10] and Suhardjanto et al. [39] suggested that the numerous audit results revealed a high degree of corruption in local government departments. Thus, the formulated the hypothesis as follows:

H3: Audit findings have a positive effect on the level of corruption.

\subsection{Law Enforcement}

The transfer of power from the center to the regions raises the agency conflicts in the public sector. These conflicts have implications for deviations and violations which harm the principle. Violations and irregularities are often created using public spending as a gap for corruptors [34]. Previous study has suggested the effective application of corruption control by law enforcement officials which consists of strict prevention, detection and enforcement measurement [20]; [21]. Decisive action is expected to be a deterrent effect for the perpetrators of corrupt practices and for those who are willing to start. Thus, the formulated hypothesis is as follows:

H4: Law enforcement can moderate the relationship between the size of government and the level of corruption.

The serious agency problems depend on the efforts of internal supervisory agencies, external oversight, the power of political leadership in controlling government at the lower levels, and the level of difference in goals between principle and agent [6]. According to Anan [5], decentralization is one of the factors contributing to the high corruption in local governments. The high number of corruption cases in local governments demonstrates the need for oversight in order to minimize corruption [14]. Regulation and law enforcement become one of the key considerations in the application of an optimal fiscal decentralization policy [40]. One theoretical basis for this policy intervention is the fiscal decentralization combined with law enforcement which helps reduce the level of corruption [6]. Thus, the formulated the hypothesis as follows:

H5: Law enforcement moderates the relationship between fiscal decentralization and the level of corruption.

Audit findings form a reflection of fraud and violations are committed by local governments during operational activities. Febrian and Rossieta [17] agree that evidence of irregularities committed by the government during the operational process can be used as a basis for law enforcement officials to carry out further investigations. This action aims to prevent further involvement of perpetrators of corrupt practices [18]; [19]; [14]. Audit findings will be able to help reduce the number of corruptions in local governments if law enforcement officials work optimally and take firm actions against corruptors. Thus, the hypothesis is as follows:

H6: Law enforcement moderates the relationship between audit findings and the level of corruption.

\section{Methodology}

District and city governments were chosen as the target population because district and city governments are the government agencies with the most corruption cases in Indonesia. In addition, district and city governments are the lowest levels of government in the decentralized system. The total population of the study was 514 (416 
district governments and 98 municipalities). The samples taken in this study were district and city governments. Furthermore, purposive sampling techniques were used to select samples based on criteria set by the entire study population. The followings are the parameters used in this sampling procedure:

(a) Based on a federal court ruling in 2019, district and city governments are presenting corruption lawsuits with permanent legal power.

(b) The district / city government owns the data from BPK RI audit findings report.

(c) For fiscal of 2019, district /city governments are completing data for all variables

Furthermore, Data was gathered through official website publications and electronic contact with appropriate agencies. The data collected consist of financial report from local government, BPK Audit Reports (LHP), Population Data, Corruption Case Reports, District Court Annual Reports, and GRDP Data. Furthermore, each variable has its own set of measurements based on previous research. Table 1 lists the variables that were measured.

\section{Result}

\subsection{Data Description}

In this study, there were 514 district and city governments in Indonesia. A purposive sampling technique was used in the sample selection process. Table 2 shows the final sample of the research.

The data population screening shown in Table 2, the outliers were identified using case-wise diagnostics, with the standard deviation serving as a benchmark. According to Sekaran and Bougie [41] stated that the standard deviation is a calculation of how much anything deviates from the data center. "If the standard deviation score of the variable exceeds the average score of the variable, it can be ascertained that the data has a low level of deviation, and vice versa" [42]. In addition, to remove extreme data, outliers were also manually removed. There were 9 city governments and 52 district governments among the samples affected by the outlier. Furthermore, after the outlier, a total of 66 district governments and 15 city governments were included in the final survey.

Table 1. Measurement of variables

\begin{tabular}{|c|l|c|}
\hline Variable & \multicolumn{1}{|c|}{ Measurement } & \multicolumn{1}{|c|}{ Source } \\
\hline Corruption & $\begin{array}{l}\text { "using a ratio between the number of corruption cases that have } \\
\text { permanent legal force and the total population per 10,000". }\end{array}$ & Liu \& Lin [10] \\
\hline Government Size & $\begin{array}{l}\text { "total regional government spending as a percentage of total Gross } \\
\text { Regional Domestic Product (PDBR)". }\end{array}$ & Changwony \& Paterson [26] \\
\hline Fiscal decentralization & $\begin{array}{l}\text { "ratio of total regional government expenditure to total central } \\
\text { government expenditure". }\end{array}$ & Liu \& Lin [10] \\
\hline Audit Findings & $\begin{array}{l}\text { "the number of audit findings on weaknesses in the internal control } \\
\text { system is added to the number of audit findings on compliance with } \\
\text { regulations". }\end{array}$ & Ko \& Zhi [6] \\
\hline Law enforcement & $\begin{array}{l}\text { "ratio of total district court expenditure to total regional government } \\
\text { expenditure". }\end{array}$ \\
\hline
\end{tabular}

Table 2. Final Samples

\begin{tabular}{|c|c|}
\hline Criteria & Total \\
\hline Population & 514 \\
\hline No corruption cases having legal force remain based on a district court ruling in 2019 & 368 \\
\hline There is no information about how many audit findings BPK RI has released & 3 \\
\hline Samples before being exposed to outliers & 143 \\
\hline Samples affected by outliers & 61 \\
\hline Final Samples & 81 \\
\hline
\end{tabular}


Table 3. Descriptive Statistics of Main Variables

\begin{tabular}{|c|c|c|c|c|c|}
\hline & N & Min & Max & Mean & Std. Deviation \\
\hline Corruption (C) & 81 & 0,00171 & 0,08894 & 0,0291016 & 0,02203642 \\
\hline Government Size (GS) & 81 & 0,01501 & 0,37641 & 0,0993951 & 0,06648367 \\
\hline Fiscal Decentralization (FD) & 81 & 0,00025 & 0,00294 & 0,0007637 & 0,00054523 \\
\hline Audit Findings (AF) & 81 & 6 & 24 & 13,51 & 3,739 \\
\hline Law Enforcement (LE) & 81 & 0,00292 & 0,04501 & 0,013408 & 0,00818201 \\
\hline Moderate Effect on GS & 81 & 0,000059268 & 0,006602669 & 0,001475999 & 0,001459932 \\
\hline Moderate Effect on FD & 81 & 0,000002013 & 0,000011953 & 0,000007882 & 0,000002905 \\
\hline Moderate Effect on AF & 81 & 0,027745951 & 0,630076499 & 0,180758287 & 0,121356457 \\
\hline
\end{tabular}

\subsection{Descriptive Statistics}

Table 3 shows the descriptive statistics of the collected data. Based on the results of the statistical test in table 3, all data on the variable has a greater mean value than the standard deviation value. This shows that the data used are homogeneous or have a low level of data deviation.

\subsection{Regression Analysis and Discussion}

The coefficients can be obtained from regression analysis for each variable and by predicting the value of an independent variable with an equation. This was applied the $t$ test to see whether the proposed hypothesis was accepted or rejected. Hypothesis testing was done using multiple linear regression methods with the following test results:

Table 4. Multiple Linear Regression Results

\begin{tabular}{|c|c|c|c|}
\hline Model & Coefficients & t & Sig. \\
\hline (Constant) & 0,025 & $-3,280$ & 0,002 \\
\hline GS & 0,086 & 2,528 & 0,014 \\
\hline FD & 11,415 & 4,653 & 0,000 \\
\hline AF & 0,003 & 5,704 & 0,000 \\
\hline LE & 5,106 & 8,749 & 0,000 \\
\hline Moderate Effect on GS & 4,507 & 2,337 & 0,022 \\
\hline Moderate Effect on FD & $-4,285$ & $-10,308$ & 0,000 \\
\hline Moderate Effect on AF & 0,232 & $-5,771$ & 0,000 \\
\hline R-Square & 0,927 & & \\
\hline
\end{tabular}

The results of the hypothesis test in table 3 find that the government size has a significant positive impact on the level of corruption in local government. It can be concluded that the greater fiscal assistance provided by the central government through balance funds can have an impact on corrupt practices that occur in the regions. This result has been predicted by previous study which states that government transactions that occur between the center and the regions have the potential to cause agency problems that can lead to irregularities and violations [28]. The reason for this is a discretionary deficit in the provision of public goods and services [33]. This gap is often used by local officials in corrupt practices [34]. This study consists with previously which predicts that size of government has a positive effect on the corruption level [9]; [33]; Liu and Lin, [10].

Corruption in procurement of goods and services occurs when local governments are given fiscal responsibility to manage their regions independently as well [6]. This statement is proven by presenting that fiscal decentralization has a positive effect on the corruption level. There are some studies mentioning that fiscal decentralization makes the government become more responsive and accountable [26]; [32]; [25]; [38]. It is caused by the negative impact of the implementation of fiscal decentralization in the unitary state, given the current context of Indonesia as a unitary state. This negative impact results from the weakness of democratic institutions, the history of colonialism, internal bureaucracy, and the validity of centralization in constitutional and decision making [25]. Consisting with result by Anan [5] stated that the high level of corruption in Indonesia is affected by the implementation of a fiscal decentralization system. The reason for this is the low level of accountability and transparency of the local governments.

The high level of corruption in the regions reflects the amount of infractions committed by local governments during the operating phase. This statement is proven by the results of the study in table 4 which shows that audit findings have a positive effect on the level of corruption. This means that the number of irregularities found during the audit process reflects the corruption level in the local government. Previous study has also agreed that the inspection mechanism carried out during the auditing process makes it possible to detect occurring fraud [15]; [13]; [19]. Huefner [16] proves that findings of control weaknesses refer to acts of non-compliance which have implications for corrupt practices. This study is in line with previously that considered audit findings to be 
commendable in light of the degree of corruption in local governments [10]; [39].

The study also added the moderating effect of law enforcement into the influence of independent variables on the dependent as a supervisory agency within the agency theory framework. Law enforcement is expected to provide a deterrent effect for perpetrators and provide additional risks for those who intend to commit corruption. However, the evidence found contradicts this. The results of this study have proven that law enforcement strengthens the influence of government size and audit findings on the level of corruption. It is caused by a decrease in the performance of law enforcement officers in Indonesia to take actions against corruption cases [2]. Choi [20] states that effective corruption control can be measured from preventive actions, detection and action from law enforcement officers [21]; [22]. In this context, the performance of 2 out of 3 law enforcement agencies experienced a significant decrease as implications for effective corruption control. In addition, the decrease in performance of law enforcement has implications for the slow process of identifying evidence of fraud committed by local governments during the operational process found during auditing. However, different results are found in moderating the effect of fiscal decentralization on the level of corruption. These results prove that the influence of law enforcement moderation weakens the effect of fiscal decentralization on the level of corruption. This shows that law enforcement in decentralized areas is running effectively. This result is in line with [6] stated that effective law enforcement is able to reduce the number of corruption cases. This is due to fiscal decentralization which helps local governments improve the quality of their government consisting of law enforcement and corruption control.

\section{Conclusion}

Corruption remains a significant problem in Indonesia. Corruption practices in government cause a series of negative effects leading to poverty [11]. The results of this study state that government size, fiscal decentralization, and audit findings had a positive significantly influence on the level of corruption and law enforcement moderate the relationship between factors and corruption level.

The findings of this study have a wide implication for auditing procedures, government administration, law enforcement, and anti-corruption efforts in Indonesian local government. Considering that corruption is still a problem in Indonesia, it is suggests that regional governments throughout Indonesia conduct governance in a transparent and accountable manner. The application of this principle is able to reduce the level of corruption in the regions. The central government is expected to be able to make policies to strengthen law enforcement agencies in Indonesia, especially anti-corruption agencies. For local governments, this literature is used as material for evaluating governments' performance in governance practices and corruption control initiatives in the regions

The prosecutor's office is also expected to strengthen supervision and prosecution of corrupt practices, especially in regencies /cities, because more corruption cases occur in regional governments. One way to do this is by increasing the number of district courts for corruption in every district /city in Indonesia in accordance with Law No. 46 of 2009 concerning Corruption Criminal Court Article 3, because currently there are only 33 district courts for corruption. In further study, it is suggested to add elements from the government internal audit findings.

\section{REFERENCES}

[1] Henderson, J. V., \& Kuncoro, A. "Corruption and local democratization in Indonesia: The role of Islamic parties," Journal of Development Economics, vol. 94, no. 2, 164-180, 2011.

[2] Indonesia Corruption Watch. "Laporan Tren Penindakan Kasus Korupsi Tahun 2019,” 2019.

[3] Transparency International. "Corruption Perceptions Index 2018," 2018.

[4] Indonesia Corruption Watch. "LaporanT ren Penindakan Kasus Korupsi Tahun 2018,” 2018. https://antikorupsi.org/sites/default/files/laporan_tren_peni ndakan_kasus_korupsi_2018.pdf.

[5] Anan, E. "Effect of Fiscal Desentralization and Region-wide Corruption Level in Indonesia." Proceedings of the International Conference of Democratisation in Southeast Asia (ICDeSA 2019), 367(ICDeSA), 246-251, 2019.

[6] Ko, K., \& Zhi, H. "Fiscal Decentralization: guilty of aggravating corruption in China?," Journal of Contemporary China, vol. 22, no. 79, 35-55, 2013.

[7] Aswar, K., \& Surbakti, L. P. "Pengaruh Desentralisasi Fiskal Terhadap Pendapatan Asli Daerah Dan Belanja Publik Kabupaten/Kota di Indonesia," Proceeding PESAT (Psikologi, Ekonomi), 2013.

[8] Magtulis, P. P., \& Poquiz, J. L. "Big Government, Big Corruption? Examining the Relationship between Government Size and Public Corruption in the Philippines," International Journal of Public Administration, vol. 40, no. 11, 954-967, 2017.

[9] Goel, R. K., \& Nelson, M. A. "Corruption and government size: A disaggregated analysis," Public Choice, vol. 97, no.1-2, 107-120, 1998.

[10] Liu, J., \& Lin, B. "Government auditing and corruption control: Evidence from China's provincial panel data," China Journal of Accounting Research, vol. 5, no. 2, 163186, 2012. 
[11] Mauro, P. "Corruption and Growth," The Quarterly Journal of Economics, vol. 110, no. 3, 681-712, 1995.

[12] Avis, E., Ferraz, C., \& Finan, F. "Do Government Audits Reduce Corruption? Estimating the Impacts of Exposing Corrupt Politicians," Journal of Political Economy, vol. 126, no. 5, 1912-1964, 2018.

[13] Hameed, F. "Fiscal Transparency and Economic Outcomes," In IMF Working Papers (WP/05/255), 2005.

[14] Olken, B. A. "Monitoring Corruption: Evidence from a Field Experiment in Indonesia," Journal of Political Economy, vol. 115, no. 2, 200-249, 2007.

[15] Brusca, I., Manes Rossi, F., \& Aversano, N. "Accountability and Transparency to Fight against Corruption: An International Comparative Analysis," Journal of Comparative Policy Analysis: Research and Practice, vol. 20, no. 5, 486-504, 2018.

[16] Huefner, R. J. "Fraud risks in local government: An analysis of audit findings," Journal of Forensic and Investigate Accounting, vol. 3, no. 3, 111-125, 2011.

[17] Febrian, A., \& Rossieta, H. "Effect of Budget Discretion on Corruption Level and Public Accountability: Evidence from Local Indonesian Government," Proceedings of the 3rd Asia-Pacific Research in Social Sciences and Humanities Universitas Indonesia Conference (APRISH 2018), 348(APRISH 2018), 212-218, 2019.

[18] Labuschagne, H., \& Els, G. "Corruption and fraud: any lessons for the auditor?," Meditari Accountancy Research, vol. 14 , no. 1, 29-47, 2006.

[19] Malagueno, R. "Accounting and corruption: a cross-country analysis," Journal of Money Laundering Control, vol. 13, no. 4, 372-393, 2010.

[20] Choi, J.-W. "Measuring the Performance of an Anticorruption Agency: The Case of the KPK in Indonesia," International Review of Public Administration, vol. 16, no. 3, 45-63, 2011

[21] MacDonald, R., \& Majeed, M. T. "Causes of Corruption in European Countries: History, Law, and Political Stability (ZDB-ID 2196257-1), 2011.

[22] Wagner, B. B., \& Jacobs, L. G. "Retooling Law Enforcement to Investigate and Prosecute Entrenched Corruption: Key Criminal Procedure Reforms for Indonesia and Other Nations," University of Pennsylvania Journal of International Law, 183-265. 2008.

[23] Adedeji, D. B., Soyinka, K. A., \& Sunday, O. M. "Corruption Control in the Public Sector and the Nigerian Accountant," International Journal of Academic Research in Accounting, Finance and Management Sciences, vol. 8, no. $1,91-103,2018$.

[24] Elbahnasawy, N. G. "E-Government, Internet Adoption, and Corruption: An Empirical Investigation," World Development, vol. 57, 114-126, 2014.

[25] Fisman, R., \& Gatti, R. "Decentralization and corruption: evidence across countries," Journal of Public Economics, vol. 83 , no. 3, 325-345, 2002.
[26] Changwony, F. K., \& Paterson, A. S. "Accounting practice, fiscal decentralization and corruption," British Accounting Review, vol. 51, no. 5, 1-21, 2019.

[27] Siburian, M. E. "Fiscal decentralization and regional income inequality: evidence from Indonesia," Applied Economics Letters, vol. 0, no. 0, 1-4, 2019.

[28] Blackburn, K., Bose, N., \& Emranul Haque, M. "The incidence and persistence of corruption in economic development," Journal of Economic Dynamics and Control, vol. 30, no. 12, 2447-2467, 2006.

[29] Tanzi, V. "Corruption, governmental activities, and markets (WP/94/99)," International Monetary Fund, 1994.

[30] Eisenhardt, K. M. "Agency Theory: An Assessment and Review," Academy of Management Review, vol. 14, no. 1, 57-74, 1989.

[31] Hay, D., \& Cordery, C. "The value of public sector audit: Literature and history," Journal of Accounting Literature, vol. 40, (November 2016), 1-15, 2018.

[32] Dong, B., \& Torgler, B. "Causes of corruption: Evidence from China," China Economic Review, vol. 26, no. 1, 152169,2013

[33] Lecuna, A. "Corruption and Size Decentralization,” Journal of Applied Economics, vol. 15, no. 1, 139-168, 2012.

[34] Zhao, X., \& Xu, H. D. "E-Government and Corruption: A Longitudinal Analysis of Countries," International Journal of Public Administration, vol. 38, no. 6, 410-421, 2015.

[35] Mello, L. de, \& Barenstein, M. "Fiscal Decentralization and Governance: A Cross-Country Analysis (WP/01/71), 2001.

[36] Kyriacou, A. P., \& Roca-Sagalés, O. "Fiscal and Political Decentralization and Government Quality," Environment and Planning C: Government and Policy, vol. 29, no. 2, 204-223, 2011 .

[37] Shah, A. "Corruption and decentralized public governance (WPS3824)" The World Bank, 2006.

[38] Ulum, A. S., Rohman, A., Harto, P., Ratmono, D., \& Ghozali, I. "The Role of Natural Resources on Moderating the Relationship between Fiscal Decentralization and Corruption: Evidence from Indonesia," International Journal of Energy Economics and Policy, vol. 9, no. 1, 67-75, 2019.

[39] Suhardjanto, D., Syarifuddin, M., Andini, R. P., \& Rahmatika, M. W. "Accountability and Corruption Level of Provincial Government in Indonesia," Review of Integrative Business \& Economics Research, vol. 7, no. 3, 281-296, 2018.

[40] Agyemang-Duah, W., Gbedoho, E. K., Peprah, P., Arthur, F., Sobeng, A. K., Okyere, J., \& Dokbila, J. M. "Reducing poverty through fiscal decentralization in Ghana and beyond: A review," Cogent Economics and Finance, vol. 6, no. 1, 1-14, 2018.

[41] Sekaran, U., \& Bougie, R. "Research Methods for Business: A Skill Building Approach,” Wiley, 2016.

[42] Cooper, D., \& Schindler, P. "Business Research Methods: 12th Edition" McGraw-Hill Higher Education, 2013. 